\title{
German Pronunciation Database and its Possible Applications in the Age of Homeschooling
}

\begin{abstract}
Orthoepy research is a traditional field at the department of Speech Science and Phonetics at Martin-Luther-University Halle-Wittenberg. After several pronunciation dictionaries, the department has now published a pronunciation database. With the establishment of the German pronunciation database (DAD), the desire for a publicly accessible reference source is met. It offers norm phonetic information on general vocabulary, as well as forms and rules of phonetical Germanization. The database can be used for various scenarios in German lessons. Continuous expansion means that further possible uses can be introduced in the future.

Keywords: history of pronunciation codification, pronunciation database
\end{abstract}

\section{Orthoepic codifications - from book to database}

The results of orthoepy research at the Department of Speech Science and Phonetics at Martin Luther University Halle-Wittenberg have been published in the form of several pronunciation dictionaries, recently the Deutsches Aussprachewörterbuch (DAWB) [German Pronunciation Dictionary] (Krech, Stock, Hirschfeld, \& Anders, 2009), which wants to be considered as the reference for German standard pronunciation. The recommended pronunciation is especially applicable in fields in which people speak consciously of form, like audio-visual media, stage, education and speech therapy (pp. 6-7). People expect the use of standard pronunciation from persons that work in these fields as Hollmach (2007) showed in a representative survey. Furthermore, the results of orthoepy research address most notably German teachers and learners in German as a foreign, second or mother language.

Robert Skoczek, Institut für Musik, Medien- und Sprechwissenschaften. Abteilung Sprechwissenchaft und Phonetik, Martin-Luther-Universität Halle-Wittenberg, Emil-Abderhalden-Str. 26, 06108 Halle (Saale), Phone: 0049034524462, robert.skoczek@sprechwiss.uni-halle.de, http://orcid.org/0000-00021495-7116

Alexandra Ebel, Institut für Musik, Medien- und Sprechwissenschaften. Abteilung Sprechwissenchaft und Phonetik, Martin-Luther-Universität Halle-Wittenberg, Emil-Abderhalden-Str. 26, 06108 Halle (Saale), alexandra.ebel@sprechwiss.uni-halle.de, http://orcid.org/0000-0001-8191-1372 


\subsection{A brief look at history: the beginnings of orthoepy research}

One of the first phoneticians, who dealt with standard pronunciation was Wilhelm Viëtor (1850-1918). In some empirical research, he asked people about their pronunciation habits, which can be seen as the first exploration of pronunciation reality. His book Die Aussprache des Schriftdeutschen [Pronunciation of written German] (1885) contains a pronunciation theory and a small dictionary with phonetic transcriptions. It can thus be considered as the first systematically applied, scientifically founded set of rules for German standard pronunciation (cf. Krech et al., 2009, p. 9). In 1912 an additional book by the author appeared, which was called Deutsches Aussprachewörterbuch [German pronunciation dictionary]. The pronunciation theory was missing in this book, but it contained a dictionary of 35,000 words in IPA transcription.

Another established codification of German standard pronunciation was published at the end of the 19th century by Theodor Siebs (1862-1941). He took the pronunciation of actors in German theatres as a basis for his recommendations. This approach was and is viewed critically to this day (cf. Hollmach, 2007, p. 69; Krech, 1957; Stock, 1996). The author's requirements were so high that even the actors were unable to meet them. But nonetheless, Siebs expanded the scope of his pronunciation norms and transferred them to other areas of communication beyond the theatre stage. Even if this led to a wave of criticism, Siebs' standards were advocated in conservative circles and are in some cases still used today.

\subsection{Orthoepy research before German reunification}

Unfortunately, in the 1950s, efforts to fundamentally revise Siebs' norms and create an all-German pronunciation dictionary failed, because this initiative was rejected by the descendants and editors of Siebs' pronunciation dictionary (cf. Hollmach, 2007, p. 79). Scientists from Halle then began with systematic research in the field of orthoepie to elaborate a conceptually new pronunciation dictionary beyond the tradition of Theodor Siebs. One of their guiding principles was that the recommendations had to be realizable. They analysed the pronunciation on the radio and examined key pronunciation features such as aspiration of plosives, the pronunciation of $\mathrm{R}$, reduction of [ə] in weak syllables and vowel quality and quantity (Krech, 1961). In 1964 the Wörterbuch der Deutschen Aussprache (WDA) [Dictionary of German pronunciation] finally appeared ${ }^{1}$.

In the years that followed, research continued in Halle and entailed some new editions of the WDA as well as an extended edition named Großes Wörterbuch der deutschen Aussprache (GWDA) [Large Dictionary of German pronunciation] in 1982. One of the novelties was the phonostylistic differentiation of standard pronunciation. It mainly referred to the research results of Gottfried Meinhold

\footnotetext{
1 Cf. Krech, Kurka, Stelzig, Stock, Stötzer and Teske (1964).
} 
(1973). He distinguished between three levels of standard pronunciation in a formal lecture, in reading manuscripts on the radio and in factual conversations (Krech et al., 1982, p. 73).

\subsection{New codification of German standard pronunciation since the 1990s}

The Deutsches Aussprachewörterbuch (DAWB) [German Pronunciation Dictionary], published in 2009, is considered to be a further development of the GWDA (cf. Hirschfeld \& Stock, 2016, p. 51). Particularly noteworthy are the sociophonetic studies, the results of which were incorporated into the development of this new dictionary. Therefore, a language that is accepted and desired throughout Germany should be evaluated. 1,700 people from different regions and social classes took part and assessed the appropriateness of various audio samples. The survey confirmed that German people have an internalized idea of standard pronunciation, even if they cannot speak it themselves (Hollmach, 2007). Further innovations and updates included the following areas (cf. Hirschfeld \& Stock, 2016, p. 51):

1. description of the three national German standard varieties in Germany, Austria and Switzerland,

2. update of the phonostylistic differentiation,

3. expansion and update of the vocabulary,

4. new codification of phonetic Germanization of foreign words and names.

A decade after the DAWB had been published it seemed a logical step to use the possibilities offered by the internet.

\section{German Pronunciation Database}

The Deutsche Aussprachedatenbank (DAD) [German Pronunciation Database] can be seen as a further development of the DAWB. It was developed by researchers at the Department for Speech Science and Phonetics at Martin Luther University Halle-Wittenberg in cooperation with the Professorship for business informatics at the Technical University of Applied Sciences Wildau (cf. Ebel, Förster \& Walther, 2021).

\subsection{From idea to implementation}

A dictionary in book format limits the utilization for users as well as researchers. This is mainly due to the limited space in books. In addition, clarity is limited when you give too much extra information for every entry. As a result, in a book, many additional details cannot be given. For example, the phonetic transcription of standard pronunciation is done using the International Phonetic Alphabet (IPA). Another phonetic spelling like XSAMPA wouldn't find a place in a dictionary and would also reduce clarity. The provision of further information is also restricted. In the $D A W B$ the lexical meaning is only given if an identically written entry has 
more than one meaning, like the German for August (month) [ag' $v s t]$ vs. August (name) ['aggost]. Further restrictions concern the naming of the indications of origin and the representation of pronunciation variants.

While the book format is associated with many restrictions, a database allows a wide range of uses and expansion options for the existing amount of data. In contrast to a linear dictionary, a web application can be used hypertextually. This makes links between individual entries possible and also to other websites that provide for example etymological information. Pronunciation databases provide several search functions, which significantly simplifies use. If you are looking for words with a certain combination of letters or even phones in certain positions or syllables, you can find them using the search box syntax. Of course, it is possible to search for IPA characters as well as XSAMPA characters and their combinations. There are also filter options to sort entries by initial letters, the indication of origin or the number of syllables. Furthermore, you can give multimedia additions like audio files that make the transcripted pronunciation audible.

\subsection{Current work status}

Since 2011, the data pool has 130,000 entries, generated out of the DAWB dictionary. This data pool was subjected to a quality assurance control with regard to correctness and completeness of the entries as well as usability and systematics (Förster, 2014). After that, some systems were tested, and the first version of the Pronunciation Database was set as a DokuWiki system. The first entries in this database can be dated to 2017. It was determined that audio files should be generated using a TTS system. For this purpose, the available data first had to be prepared and supplemented with additional metadata (Drechsel, 2020). Since the middle of 2020 , the DAD is being re-engineered to overcome weaknesses that arose from the old DokuWiki system.

At the moment you can use the DAD only after registration. You can search for single entries, either in their graphemic form or in the IPA transcription. The phonetic search is a central component of DAD and is supported by a virtual IPA keyboard that maps all vowels, consonants, diacritics and suprasegmentals according to the International Phonetic Alphabet.

An entry in the DAD consists of five or six lines. A sixth line comes into play when entries have a foreign language origin. The first line is the word in graphemic form. Below is the transcripted pronunciation with IPA characters. In lines three and four you can find information on the number of syllables and the accent pattern (cf. chapter 2.3). At the bottom, the transcription in XSAMPA characters is given. Moreover, you can display alphabetically sorted word lists. In these lists information is given about transcription, foreign origin and the number of syllables. Every word entry can be clicked on the lists so that you arrive at the webpage for that entry with its informational lines. 


\subsection{Further developments of the German Pronunciation Database}

The beta version of the DAD currently in use is the web-based Open Source wiki software DokuWiki. The application enables user administration and rights assignment, editing and research as well as versioning of changes. A new concept envisages using the web framework Django which gives the flexibility to implement complex features that cannot be realised with DokuWiki as Django is a very versatile framework for web applications.

In addition to the changes in the database structure, corrections are currently being made to individual words as well as groups of words with similar uncertainties. One important field concerns the indication of origin. This additional information is not used to identify the geographical but the linguistic origin of a word or name. For every entry with a foreign pronunciation, the origin is already indicated in the DAWB. In the course of corrections, these indications in the DAD will be written out. For example, the abbreviated spelling of the origin engl. is now given as englisch. If a word is a combination of two words with different origins, both indications shall be written out, like Stretchlimousine (straight limo) which is a combination of English and French origin, so that it is represented as englisch + französisch [English + French] in the database. Another case is words that have entered German through a third language, e.g., Georgian, that entered German via Russian as an intermediary language or Catalan and its intermediary language Spanish. In those cases, both languages are given in the DAD as georgisch-russisch (Georgian-Russian) and katalanisch-spanisch (Catalan-Spanish) respectively. In connection with these adjustments, the indications of origin were also checked, and incorrect indications were changed.

A related problem concerns homography. This term means that two words are written the same but pronounced differently. Different cases can be distinguished:

- One word from one language can be pronounced in different ways, but that doesn't affect the meaning (homosemy), like Strategie (strategy), that can be pronounced [jtøaateg'i:] or [sţ̋ateg'i:].

- Two (or more) words with different meanings (polysemy), that come from the same language are pronounced differently, e.g., Hochzeit which means wedding if you pronounce it [h'oxtsaçt] but means heyday if you pronounce it [h'o:xtsą̧ t].

- Two (or more) homoseme words that are differently pronounced in various languages, for example, the name Adam which has five entries in the dictionary: ['a:dam] (without an indication of origin, because it's the German pronunciation), ['edəm] (English), [ad'ã] (French), [ad'a:m] (Russian), ['adam] (Czech). It seems worth mentioning that the pronunciations of foreign origin do not represent the original pronunciation in the respective language of origin but the phonetically Germanized pronunciation. For 
more information about phonetically Germanization in orthoepy see e.g. Ebel, Lange and Skoczek (2014).

- Two (or more) polyseme words that are differently pronounced in various languages, for example, Komplet means the Christian Night Prayer if you pronounce it [kompl'e:t] (Latin origin) or it means two coordinated garments if you pronounce it [kompl'e:] (French origin).

Those four groups require different representations in the database. For every case, it was discussed if they should appear in one entry with two (or more) transcriptions and the respective indication of meaning or in several singular entries - one for every meaning.

The last discussion that is in progress affects the accent patterns. In the DAD for every entry, such a pattern is given. Using those patterns, you can distinguish not only between stressed syllables and those without stress, but you can better differentiate unstressed as well as secondarily stressed syllables.

The accent pattern displays the accent level assignment which was carried out automatically based on complex rules (cf. Drechsel, 2020, pp. 57-63). This approach was particularly important with regard to speech synthesis. In German standard pronunciation, we find a typical rhythm, that is created by a change from stressed and non-stressed syllables. To depict this rhythmic structure all entries were provided with a four-level pattern:

- Level 4 represents the primary stressed syllable. Every word has only one primary stress.

- Level 3 marks all syllables that are secondarily stressed. Not every word contains a secondary stress, but there are also words with more than one, like multi-part compounds.

- Level 2 indicates all syllables that could potentially be stressed in German standard pronunciation but aren't stressed in the concrete word.

- Level 1 marks syllables that cannot be stressed in neutral realization (not emotional, not contrasting) of German standard pronunciation. That concerns syllables which include German reduction vowels [ə] or [e] or elided vowels.

For example, the word Geburtsurkunde [birth certificate] [gəb 'u: ${ }^{\mathrm{pt}} \mathrm{s}^{\mathrm{u} u} \mathrm{:}^{\mathrm{e}} \mathrm{k}_{\text {, }}$ ondə] has the accent pattern 14231. It is possible, especially in words with few syllables, that not every accent level is represented. The word Juniorprofessor [junior

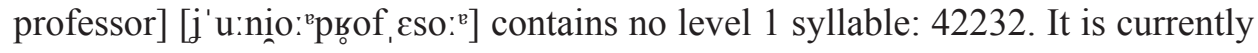
being discussed to establish a fifth level to be able to distinguish the secondary stresses in words with more than one secondary stress. The previous level 4 would become level 5 and the previous level 3 would be modified into level 4 for secondary stress and level 3 for reduced secondary stress. In the word Betreuungssituation (care situation) [bətó 'ọoryszituatsi, o:n] the accent pattern with differentiated secondary stresses would be 1523224 . 


\subsection{Future potential of the database}

The most urgent point for future work on the DAD is the completion of all entries with audio files. The addition of audio files is certainly one of the greatest advantages that pronunciation databases have over dictionaries, because many users are not used to reading the phonetic transcription and have difficulties realizing the pronunciation information correctly. But for optimal usability, some criteria for audio files should be considered. Various TTS systems are currently being tested to see which one best meets the requirements.

Another idea that is more related to the content is to group the vocabulary. So, users could selectively display words from certain categories. Different classifications are conceivable. It would be possible to sort all words of the basic vocabulary according to the learning level corresponding to the Common European Framework of Reference for Languages. Terms that are often used in certain situations could also be grouped together (e.g. in a restaurant, at the doctor's, terms from the field of politics, chemical elements, toponyms, athlete names etc.). Another important target is to add inflected forms to the DAD. Especially for learners of German as a foreign language, not only the pronunciation of an infinitive is of interest, but also inflexion forms. To give an example: the German verb sprechen shows the following stem forms: spricht - sprach - hat gesprochen. These inflexion forms go with a vowel change. This, in turn, is associated with a change in the subsequent fricative, because in German the standard pronunciation $\langle\mathrm{ch}>$ is realized as [c] only after front tongue vowels, while it is realized as

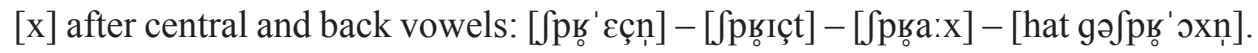
Of course, these extensions should be supplemented by audio files, too.

\section{Explanations on the DAD Database in online teaching}

The last two years, linked to the current epidemiological situation, have brought many changes in the organisation of teaching. Teachers and learners not only had to get used to the new forms and methods but also new programmes and tools useful for homeschooling. The German Pronunciation Database (DAD) developed in Halle is becoming more relevant in this situation. As outlined above, the DAD offers several useful functions. On the one hand, it can be used as an online dictionary, and on the other hand, it can be used as a database by its filter functions in the online teaching of German as a mother tongue (DaM) and of German as a second language (DaZ) and as a foreign language (DaF). The following are some ways to use the German pronunciation database.

\subsection{The DAD potential in the field of DaM}

The aim of German teaching in primary schools is to provide pupils with a language education so that they are able to act appropriately in current and future life situations. 
The subject of German as a mother tongue is speaking and writing as specific oral and written forms of German. Basic language skills are acquired in the first years of school. The pupils should learn to spell correctly, among other things. The following language skills are trained according to educational standards through appropriate support measures (cf. internet source 1):

- the recognition of the correlations between spelling and pronunciation,

- the use of basic legal orthographic strategies,

- the principle of synthesis when reading and reproducing the content,

- the differentiation of language sound phenomena,

- the corresponding spelling and taking into account of orthographic and morphological rules,

- the syllabification of words,

- the use of punctuation marks,

- the distinction between regional and standard languages,

- the recognition of design features in audio texts, such as voice guidance, speech pauses, and speech tempo.

With the above-mentioned requirements for the students of German as a mother tongue, the phonetic competence is gradually deepened in addition to the awareness of spelling rules. At the same time, these guidelines on educational attainment presuppose the language knowledge of primary school teachers.

On the one hand, the DAD offers comprehensive descriptions of the German sound system and can serve as the basis for further training for the teachers. On the other hand, the use of the DAD can also be used in online lessons.

For example, the following tasks could be prepared with the DAD:

- How many syllables do the following animal names consist of? Clap and say the words out loud! Please check the solution in the DAD?

Siamkatze, Giraffe, Krokodil, Hund, Zwergpinscher, Papagei, Wellensittich

- The letters $s, s s$ and $\beta$ are missing in the following words. Make the plural forms of them and compare the spelling with data in the DAD! What letter is missing? Fill in the correct letters:

$\mathrm{Fa}, \mathrm{Fu}_{\ldots}, \mathrm{Nu} \_$, Hau_, Gru_, Spa_, Lo

- Fill in the gaps in the text. What letters are missing? Check the pronunciation in the DAD and compare it with the spelling rules.

wei Ka__en wollten mal einen Tiger im _ oo besuchen. Sie gingen uerst in ein Geschäft rech__ daneben. „Vielleicht kaufen wir ihm schwar Schuhe für seine Ta_en? - schlug die eine Ka_ e vor. „Das ist doch ein Wi_ !“ - entgegnete die andere Ka_e. Im __ oo wird im Winter gehei_t und er si_ $t$ eh nur im Käfig." Sie fanden leider nich_, was dem Tiger gefallen könnte. Sie hatten die Schnau_e voll und waren schon etwas gerei_t. „Ohne Geschenk ist doch doof! Wir kaufen ihm diese Kra__bürste." Der stol_ Tiger tan_te vor 
Freude, nicht weil er sich mit der Bürste nun kra en konnte, sondern weil ihn seine Freunde nicht vergessen haben.

The teachers can use the DAD in many ways in online lessons. In higher-level classes, foreign words, technical terms, and homonyms can be accessed by a phonetic script and other metadata for individual keywords.

\subsection{The DAD potential in the field of DaZ/DaF}

German as a Second Language (DaZ) refers to the teaching and use of the German language in a German-speaking environment. In preparatory classes, pupils with little or no knowledge of German acquire the basics of the German language in order to prepare themselves for life and school attendance in Germany.

The subject of German as a Foreign Language (DaF) aims to develop language skills only in school or in language courses. In contrast to DaZ learners, DaF learners operate outside the school in a non-German-speaking environment. Nevertheless, common objectives can be set for both groups of education, which derive from the Common European Framework of Reference for Languages (internet source 2) and the Education Standards for Primary Schools (internet source 3).

Pronunciation training is integrated into foreign language learning as a part of receptive and productive skills. Listening, speaking, reading and writing take place in parallel in the DaZ/DaF classes. In doing so, the learners refer to their first language, link new sounds with their own learning speech patterns and do not notice the differences. Therefore, both elementary hearing to identify and discriminate new prosodic patterns and sounds and their combinations, and new articulation habits must be developed. In this respect, transforming what was heard into writing and of written texts into the intelligible acoustic form in the area of DaZ/DaF differ significantly from that of the subject of DaM (cf. Hirschfeld \& Reinke, 2016, p. 83).

The DAD is thus able to support the teachers, particularly in their teaching design in a variety of ways. In the DAD, German teachers and students will find the basic information on the following topics:

- the phonetics system of the German standard speech,

- accent rules,

- intonation patterns,

- grapheme-phoneme-correspondence,

- the pronunciation of foreign words and names,

- the pronunciations of homosemes, homographs,

- the standard varieties of German.

In contrast to common pronunciation dictionaries, the DAD will in the future offer the possibility of sorting words according to level by the filter functions. The teachers can thus create word lists with the transcriptions they need for German lessons and prepare learners specifically for Goethe-Institute certificate 
examinations ${ }^{2}$. In addition to simple words, the transcriptions of common composites can be found in the DAD. Their construction can bring about changes at both the suprasegmental and the segmental levels. For example, progressive devoicing: Erdbeere ['е:'tbe:вә] or accent shifts caused by a stress clash, e.g. Schulausflug ['u:laossfl, u:k].

The knowledge of IPA transcription should not be the goal itself in the context of foreign language didactics. The aim is to make learners aware of the phonetic differences in German which affect individual sound segments as well as sound sequences. From the entire inventory of sound signs, only those symbols should be used which can be used to illustrate the typical features of standard German speech. German learners should gradually become familiar with the sound signs in the language acquisition process. This is about passive, receptive skills.

The phonetic description of Standard German and pronunciation training are also among the canonical contents of German studies abroad. As a result, the DAD can be addressed to many target groups.

For practice-oriented language teaching, the following tasks could be offered at an early stage:

- Check and mark the accent positions in country names and in derived languages in the DAD, e.g. China - chinesisch, Italien - italienisch etc. The task is undoubtedly suitable as a form of exercise, which can also be used as basic teaching material in German courses. German students and German learners are made aware that the accent-syllables in the derivatives change.

- Check the length and shortness of the accent vowels in the DAD and compare them with the spelling. Transcribe the accent vowels and add a table with simple rules, e.g. der Vater, die Mutter, der Sohn, die Tochter, die Oma, der Opa, der Schwager, die Schwägerin, die Nichte, der Neffe.

- The final devoicing principle awareness, e.g. das Aas vs. er aß [a:s], das

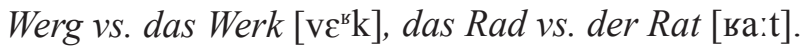

\section{Conclusion}

Acquiring phonetic competence in the $\mathrm{DaM} / \mathrm{DaF} / \mathrm{DaZ}$ teaching is essential for the promotion of learner autonomy in dealing with pronunciation codes and thus for the successful application of new vocabulary in speech-language communication. Since there is currently a lack of a scientifically sound pronunciation code with public access on the Internet, the DAD fills this gap, especially since it can be installed efficiently on a variety of devices. Such a tool is always at hand and is used as a teaching aid. As a database, however, the DAD is not a teaching tool, but it can complement and make online teaching more attractive.

2 With kind permission of the Goethe-Institut, Germany, we also use words from the word lists for the Goethe-Zertifikat A1, Goethe-Zertifikat A2 and Goethe-Zertifikat exams B1, see www.goethe.de/pruefungen. 


\section{References}

Drechsel, S. (2020). Aufbereitung des Halle-Korpus für die maschinelle Verarbeitung. In A. Ebel (Ed.), Anwendungsbeispiele neuer und etablierter Analyseverfahren in der sprechwissenschaftlichen Phonetik und Rhetorik (pp. 45-65). Retrieved June 16, 2021, from https://opendata.uni-halle.de//handle/1981185920/32700.

Ebel, A., Förster, J., \& Walther, M. (2021). Developing the German Pronunciation Database (DAD) - an online dictionary for spoken German. In S. Hillmann, B. Weiss, T. Michael, \& S. Möller (Eds.), Elektronische Sprachsignalverarbeitung 2021. Tagungsband der 32. Konferenz Berlin, 3.-5. März 2021 (pp. 216-222). Dresden: TUDpress.

Ebel, A., Lange, F., \& Skoczek, R. (2014). Ausspracheangaben zu eingedeutschten Namen in Aussprachewörterbüchern. Lexicographica, 30, 323-349.

Förster, J. (2014). Aufbau und Entwicklung der Deutschen Aussprachedatenbank (DAD). Softwarequalitätssicherung für ein digitales Aussprachewörterbuch. In A. Ebel (Ed.), Aussprache und Sprechen im interkulturellen, medienvermittelten und pädagogischen Kontext (pp. 105-117). Retrieved June 16, 2021, from https://digital.bibliothek.uni-halle.de/pe/urn/ urn:nbn:de:gbv:3:2-24373.

Hirschfeld, U., \& Stock E. (2016). Sprechwissenschaftliche Phonetik. In I. Bose, U. Hirschfeld, B. Neuber, \& E. Stock (Eds.), Einführung in die Sprechwissenschaft (pp. 27-81). Tübingen: Narr.

Hollmach, U. (2007). Untersuchungen zur Kodifizierung der Standardaussprache in Deutschland. Frankfurt am Main: Peter Lang Verlag.

Krech, E.-M., Kurka, E., Stelzig, H., Stock, E., Stötzer, U., \& Teske, R. (1964). Wörterbuch der deutschen Aussprache. Leipzig: VEB Bibliographisches Institut.

Krech, E.-M., Kurka, E., Stelzig, H., Stock, E., Stötzer, U., \& Teske, R. (1982). Großes Wörterbuch der deutschen Aussprache. Leipzig: VEB Bibliographisches Institut.

Krech, E.-M., Stock, E., Hirschfeld, U., \& Anders, L. C. (2009). Deutsches Aussprachewörterbuch. Berlin, New York: De Gruyter.

Krech, H. (1957). SIEBS Deutsche Hochsprache, Bühnenaussprache hrsg. von Helmut de Boor und Paul Diels, 16., völlig neubearb. Aufl., Berlin 1957, Walter de Gruyter u. Co. - Besprechung. Zeitschrift für Phonetik und allgemeine Sprachwissenschaft, 10, 293-298.

Krech, H. (1961). Bericht über den Stand der Arbeit am „Wörterbuch der allgemeinen Hochlautung“. In H. Krech (Ed.), Beiträge zur deutschen Ausspracheregelung. Bericht von der V. Sprechwissenschaftichen Fachtagung des Instituts für Sprechkunde und Phonetische Sammlung der Martin-Luther-Universität Halle-Wittenberg, vom 1. bis 3. Juli 1960 (pp. 48-55). Berlin: Henschelverlag.

Meinhold, G. (1973). Deutsche Standardaussprache. Lautschwächungen und Formstufen. Jena: Veröffentlichung der Friedrich-Schiller-Universität Jena.

Stock, E. (1996). Die Siebssche Aussprachekodifizierung als historisches Problem. In E.-M. Krech, \& E. Stock (Eds.), Beiträge zur deutschen Standardaussprache (pp. 41-56). Hanau, Halle: Verlag Werner Dausien.

\section{Internet sources retrieved June 17, 2021}

https://www.schulimpulse.de/rechtschreibung-in-der-grundschule-progression-der-lernziele-undlerninhalte-im-lehrplan/

https://www.coe.int/en/web/common-european-framework-reference-languages

https://www.hamburg.de/bildungsplaene/2361914/primarschule-start/ 